\title{
Circulating human pregnancy zone protein and oestriol in twin pregnancies
}

\author{
J. G. Westergaard*, A. Bach $\dagger$, B. Teisner $\dagger$, J. Hauł and \\ J. G. Grudzinskas $\S$
}

*Institute of Obstetrics and Gynaecology, $†$ Medical Microbiology and $\ddagger$ Laboratory Animal

Unit, Odense University, DK-5000 Odense C, Denmark and §Department of Obstetrics and

Gynaecology, University of Sydney, Sydney, New South Wales 2000, Australia

\begin{abstract}
Summary. Women with twin pregnancies were matched with those carrying singleton pregnancies ( $n=35$ for both) for features which are considered to influence pregnancy zone protein (PZP) concentrations. The mean PZP level was significantly lower $(P<0.01)$ and the mean total oestriol level was higher $(P<0.001)$ in twin than in singleton pregnancies. PZP levels were negatively correlated to oestriol levels in twin $(r=-0.5756, P<0.001)$ and singleton $(r=-0.3821, P<0.01)$ pregnancies.
\end{abstract}

\section{Introduction}

Pregnancy zone protein (PZP), also known as alpha-2 pregnancy associated glycoprotein, is a high molecular weight glycoprotein with alpha-2 electrophoretic mobility (von Schoultz \& Stigbrand, 1974). Circulating PZP is present in low concentrations in normal individuals of both sexes (Damber, von Schoultz, Stigbrand \& Carlström, 1976a; Folkersen et al., 1981), the levels being generally higher in females (Folkersen et al., 1981), following oestrogen therapy (Beckman, von Schoultz \& Stigbrand, 1973) and during pregnancy (Stimson, 1975). Therefore, the synthesis of this molecule, which has been demonstrated to inhibit transformation of lymphocytes in vitro (Stimson, 1976), has been presumed to be regulated by oestrogens. However, an age-dependent increase in PZP concentrations in particular in postmenopausal women has been reported (Damber, von Schoultz \& Stigbrand, 1976b; Folkersen et al., 1981).

In the light of these paradoxical findings, we have examined here maternal PZP levels in 35 patients with twin pregnancies and matched singleton controls in relation to circulating feto-placental oestrogens.

\section{Materials and Methods}

Subjects. Venous blood samples $(n=171)$ were obtained at regular intervals from 35 women with retrospectively defined normal twin pregnancies. Thirty-five samples were obtained from 35 women, with normal singleton pregnancies, who were matched for age, parity, pre-pregnancy weight, stage of gestation at time of sampling and fetal sex. Serum was separated within $2 \mathrm{~h}$ of collection, divided into aliquots and stored at $-70^{\circ} \mathrm{C}$ until assayed.

Assays. Pregnancy zone protein was quantified by rocket immunoelectrophoresis as previously described (Teisner et al., 1981). The normal range was based on the measurements of 
2317 samples from 721 women with normal singleton pregnancies. The concentration of PZP is given in arbitrary units (AU), $100 \mathrm{AU} / \mathrm{ml}$ being the concentration of PZP in a pool $(n=212)$ of late pregnancy serum. Serum total oestriol measurements were carried out with a commercial radioimmunoassay kit from the Radiochemical Centre, Amersham, U.K., and the local normal range was based on measurements of 1210 samples from 627 women with normal singleton pregnancies.

Statistics. All data were computer stored and the statistical analyses were performed according to the Statistical Package of the Social Sciences (Nie, Hull, Jenkins, Steinbrenner \& Bent, 1975).

\section{Results}

Maternal levels of PZP and oestriol during the second half of twin pregnancy in relation to the $90 \%$ confidence limits for normal singleton pregnancy are shown in Text-fig. 1. Concentrations of PZP were generally lower in twin pregnancy, 21 of $171(15.8 \%)$ values being below the 5 th percentile and 7 of $171(4.1 \%)$ values being above the 95 th percentile. Concentrations of total oestriol were generally higher in twin pregnancy, only 18 of $171(10.5 \%)$ values being below the median for singleton pregnancy and 75 of $171(43.8 \%)$ values being above the 95 th percentile.

In the comparison of matched samples from singleton pregnancies, the mean PZP concentration was significantly lower in twin pregnancy $(P<0.01)$ (Table 1$)$. By contrast, the mean total oestriol level was significantly higher $(P<0.001)$.

Table 1. Comparison of serum mean concentrations of PZP and oestriol in twin pregnancies and matched normal singleton pregnancies

\begin{tabular}{lrl}
\hline & PZP $(\mathrm{AU} / \mathrm{ml})$ & Oestriol $(\mu \mathrm{mol} / \mathrm{l})$ \\
\hline Twins & $71.5 \pm 19.4^{*}$ & $6.41 \pm 1.62^{* *}$ \\
Singletons & $120.3 \pm 14.4$ & $3.64 \pm 1.60$ \\
\hline
\end{tabular}

Values are mean \pm s.d. for 35 samples.

The data were transformed (PZP, square root; oestriol, $\log 10$ ) before analysis by Student's $t$ test: ${ }^{*} P<0.01,{ }^{* *} P<0.001$ compared with value for singletons.

There was an inverse relationship between PZP and oestriol in matched samples from both the twin and singleton pregnancies examined, $r=-0.5756(P<0.001)$ in twins, and $r=$ $-0.3821(P<0.01)$ in singleton pregnancies. There were no statistically significant correlations between PZP or oestriol levels and placental or fetal weight or fetal sex.

\section{Discussion}

The estimation of circulating PZP in multiple pregnancy has presented a unique opportunity for the further study of regulatory mechanisms of this molecule in the presence of high endogenous oestrogen concentrations. As in pregnancies with singletons PZP levels in twin pregnancies were higher than those in non-pregnant women. However, PZP values were generally lower in twin than in singleton pregnancies, not only when compared with the normal range, but also in samples obtained from patients matched for features considered to influence PZP levels. 


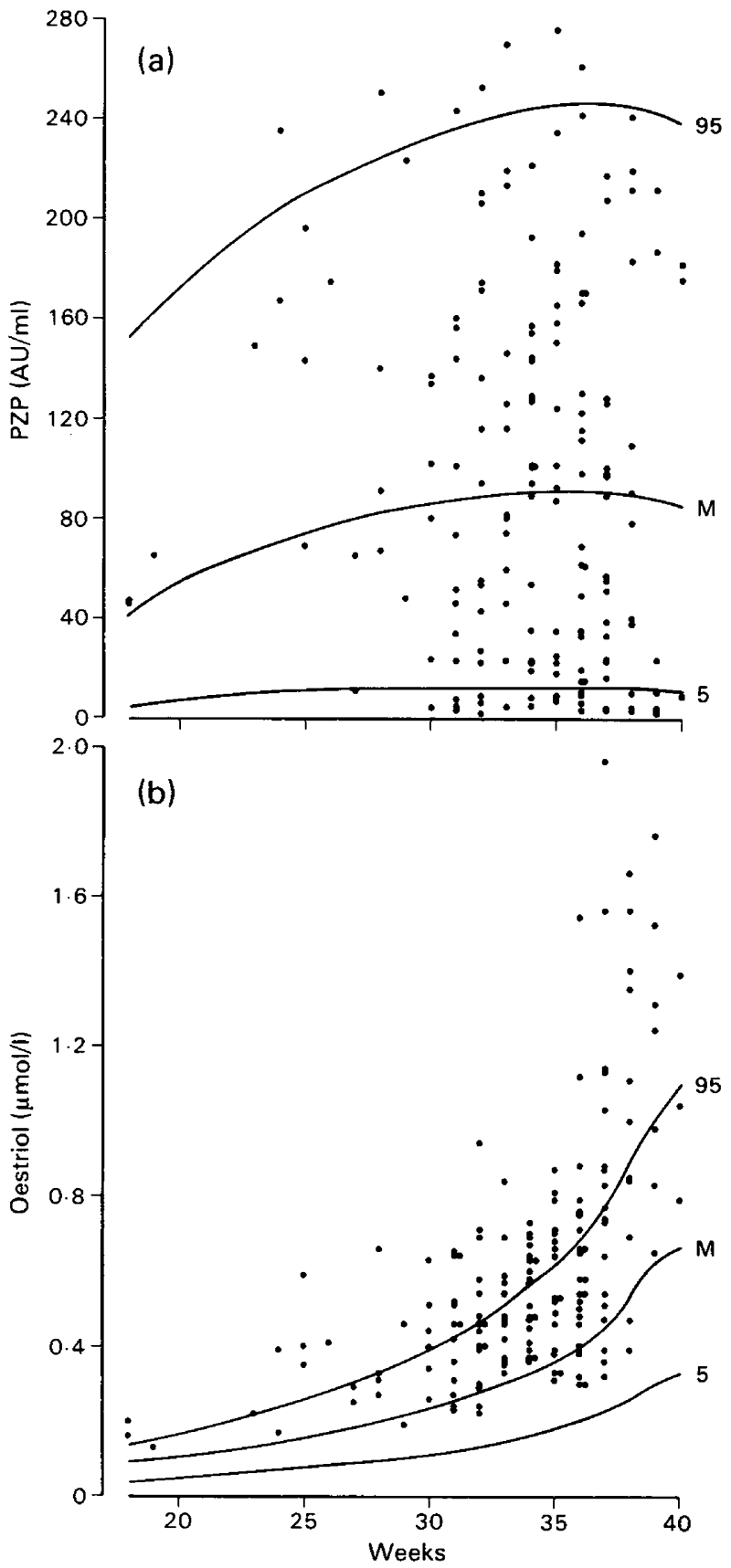

Text-fig. 1. Circulating levels of (a) PZP and (b) oestriol in 35 normal twin pregnancies (95, M and 5 refer to the 95 th, 50 th and 5 th percentile of the range in normal singleton pregnancies).

Furthermore, despite the continuing increase in oestriol levels with advancing gestation, concentrations of PZP had reached a plateau in midpregnancy which was maintained until term. The inverse relationship between PZP and oestriol was an unexpected new finding, in particular since the negative correlation was greatest in twins. 
These observations have important implications on our present understanding of the function and regulation of PZP. Firstly, further doubt can be cast on the generally accepted hypothesis that PZP synthesis is a simple function of oestrogen concentration. This concept has previously been questioned in the light of high PZP levels seen in postmenopausal women (Damber et al., 1976b; Folkersen et al., 1981). In addition, contrary to the situation in man, exogenous oestrogen administration causes a fall in serum PZP analogue levels in the African green monkey (Cercopithecus aethiops) (Teisner, Folkersen, Svendsen, Hau \& Hindersson, 1979). Secondly, the significant inverse relationship between PZP and oestriol, more pronounced in twin pregnancy, suggests that, if endogenous oestrogen does induce PZP synthesis, a more powerful and as yet unidentified modulator may be active. Testosterone suppresses PZP analogue (pregnancy associated murine protein-1) levels in male and female mice (Hau, Svendsen, Teisner \& Grudzinskas, 1982) and we are currently examining this possibility in man. An alternative hypothesis may be that PZP, the synthesis of which is induced by endogenous oestrogens, is removed from the circulation by increasing trophoblastic mass as pregnancy progresses, but we found no evidence for this here.

This work was supported by The Danish Medical Research Council (grants nos 12-1794, 512-20627 and 12-0084) and Direktør Jacob Madsen og Hustru Olga Madsens Fond. We thank Mrs Jette Brandt for expert technical assistance and Dr P. Gaede, Hillerød Hospital, for help with the oestriol analysis.

\section{References}

Beckman, L., von Schoultz, B. \& Stigbrand, T. (1973) Pregnancy zone protein in sera from patients with prostatic cancer treated with oestrogens. Urol. Res. 1, 67-69.

Damber, M.-G., von Schoultz, B., Stigbrand, T. \& Carlström, K. (1976a) A radioimmunoassay for "the pregnancy zone protein". Clin. Chim. Acta 66, 85-88.

Damber, M.-G., von Schoultz, B. \& Stigbrand, T. (1976b) On the occurrence of the pregnancy zone protein in gynaecological cancer. Arch. Gynäk. 221, 97-101.

Folkersen, J., Teisner, B., Grunnet, N., Grudzinskas, J. G., Westergaard, J.G. \& Hindersson, P. (1981) Circulating levels of pregnancy zone protein: Normal range and the influence of age and gender. Clin. Chim. Acta 110, 139-145.

Hau, J., Svendsen, P., Teisner, B. \& Grudzinskas, J.G. (1982) The regulation of pregnancy associated murine protein 1 by gonadal steroids. J. Reprod. Fert. 66, 273-275.

Nie, N.H., Hull, C.H., Jenkins, J.G., Steinbrenner, K. \& Bent, D.H. (1975) Statistical Package for the Social
Sciences, 2 edn. McGraw Hill Book Company, New York.

Stimson, W.H. (1975) Variations in serum concentrations of human pregnancy associated alphamacroglobulin during pregnancy and after delivery. J. Reprod. Fert. 43, 579-582.

Stimson, W.H. (1976) Studies on the immunosuppressive properties of a pregnancy associated alpha-2-macroglobulin. Clin. exp. Immunol. 25, 199-206.

Teisner, B., Folkersen, J., Svendsen, P., Hau, J. \& Hindersson, P. (1979) Demonstration of an analogue to human pregnancy zone protein in the African green monkey. J. med. Primatol. 8, 298-304.

Teisner, B., Lange, A.P., Folkersen, J., Anthonsen, H., von Schoultz, B. \& Stigbrand, T. (1981) Serum levels of "the pregnancy zone protein" during short-term prenatal dexamethazone therapy. Acta obstet. gynec. scand. 60, 161-164.

von Schoultz, B. \& Stigbrand, T. (1974) Characterization of the pregnancy zone protein in relation to other alpha-2 globulins of pregnancy. Biochim. Biophys. Acta 359, 303-310.

Received 19 April 1982 